\title{
PENGARUH TINGKAT SUKU BUNGA, NILAI TUKAR RUPIAH DAN JUMLAH EKSPOR TERHADAP TINGKAT KREDIT PERBANKAN
}

\author{
Yoda Ditria $^{1}$; Jenni Vivian ${ }^{2}$; Indra Widjaja ${ }^{3}$
}

\begin{abstract}
Interest rates level, exchange rates value and the export quantity are the variables of macroeconomy that always change according to the economic condition of a nation. A good knowledge about the effect of these three variables towards the amount of lending by banks, which consists of three kinds: working capital loan, investment loan, and consumption loan, will help banks' strategic plan to face the economic volatility.

Bank is a financial institution that serves as a bridge between parties that have excess funds with parties that need some funds. Banks are expected to provide loans to the public to sustain economic growth with prudence to reduce the risks, which can be customer risks or systemic risks.

The goal of this research is to study the effects and relationship between interest rates level, exchange rates movement, and export quantity towards the credit level of banks and also the three kinds of bank loans, which are the working capital loan, investment loan and consumer loan using historical data from Quarter I 2002 to Quarter III 2007.

The result of research indicates that the macroeconomic variables above affect the amount of lending and the three kinds of loan: working capital loan, investment loan and consumer loan. The result also shows that although the three macroeconomic variables have the same influence towards the three kinds of loan, the magnitude of the influence towards each kind of loan is different, in which the investment loan has a big influence towards the interest rates level change, working capital loan has a big influence towards the export quantity and exchange rates, and consumer loan has a moderate influence towards the variation of the three macroeconomic variables.
\end{abstract}

Keywords: interest rates level, exchange rates value, export quantity, bank, loan, working capital loan, investment loan, consumer loan.

\begin{abstract}
ABSTRAK
Tingkat suku bunga, nilai tukar mata uang dan jumlah ekspor adalah variabel-variabel makro ekonomi yang selalu berubah sesuai dengan kondisi ekonomi pada suatu negara. Pengetahuan yang baik mengenai pengaruh ketiga variabel ini terhadap jumlah kredit perbankan yang terbagi menjadi tiga macam, yaitu kredit modal kerja, kredit investasi dan kredit konsumsi akan sangat membantu perencanaan strategis perbankan menghadapi volatilitas perekonomian.
\end{abstract}

${ }^{1,2,3}$ BINUS BUSINESS SCHOOL, BINUS UNIVERSITY, JWC Campus, Jl. Hang Lekir I No. 6, Kebayoran Baru, South Jakarta 12120, indraw63@yahoo.com 
Bank merupakan suatu lembaga keuangan yang berfungsi sebagai jembatan antara pihak yang kelebihan dana dengan pihak yang memerlukan dana. Bank diharapkan dapat memberikan kredit kepada masyarakat sehingga perekonomian dapat terus tumbuh, namun dengan tetap memperhatikan prinsip kehatian-hatian untuk dapat mengurangi resiko baik resiko nasabah maupun resiko sistemik.

Penelitian ini bertujuan untuk mengetahui hubungan dan pengaruh antara tingkat suku bunga, perubahan nilai tukar rupiah dan jumlah ekspor terhadap tingkat kredit perbankan dan juga ketiga macam jenis kredit perbankan yaitu, kredit modal kerja, kredit investasi, dan kredit konsumsi yang menggunakan data historis dari periode kuartal I 2002 s/d kuartal III 2007.

Hasil penelitian menunjukan bahwa variabel-variabel makro ekonomi tersebut berpengaruh terhadap jumlah kredit maupun ketiga jenis kredit modal kerja, kredit investasi, dan kredit konsumsi. Namun dari hasil penelitian diketahui juga walaupun ketiga variabel makro tersebut mempunyai pengaruh yang sama terhadap ketiga jenis kredit tersebut, tetapi besarnya pengaruh terhadap masing- masing jenis kredit berbeda - beda, dimana kredit investasi memiliki pengaruh terbesar terhadap perubahan tingkat suku bunga, kredit modal kerja memiliki pengaruh terbesar terhadap perubahan jumlah ekspor dan perubahan nilai tukar, dan kredit konsumsi berada ditengah-tengah untuk sensitifitas pengaruh dari perubahan ketiga varibel makro tersebut.

Kata kunci : tingkat suku bunga, nilai tukar rupiah, ekspor, bank, kredit, kredit modal kerja, kredit investasi, kredit konsumsi. 


\section{PENDAHULUAN}

Perekonomian suatu negara digerakkan antara lain oleh sektor riil dan jasa, dimana untuk berkembang dibutuhkan suntikan dana sebagai investasi maupun modal kerja. Ada beberapa cara untuk mendapatkan dana dan salah satu yang paling umum adalah kredit melalui perbankan.

Peranan perbankan dalam pertumbuhan ekonomi sangat penting, karena fungsinya sebagai lembaga intermediasi untuk menjembatani antara pemilik dana dan peminjam. Di Indonesia pun demikian bank memiliki peranan penting dalam menggerakkan sektor perekonomian dengan cara memberikan kredit agar sektor riil berkembang.

Potensi penyerapan kredit di Indonesia juga masih sangat besar, seiring dengan membaiknya perekonomian pasca krisis moneter tahun 1997. Dari segi pembiayaan untuk kredit bank juga masih memiliki ruang yang besar untuk ekspansi, hal ini dapat dilihat dari Loan to Deposit Ratio(LDR) industri yang secara keseluruhan masih berada di angka $64 \%$ (berdasarkan data Statistik Perbankan Indonesia per Juni'07) yang artinya bank-bank dapat lebih agresif untuk melemparkan kredit kepada sektor riil.

Dalam memberikan kredit, bank membagi kredit nya menjadi tiga macam menurut kegunaannya, yaitu : kredit modal kerja, kredit investasi, dan kredit konsumsi. Dengan pembagian kredit menurut kegunaannya ini bank dapat menyesuaikan layanan pemberian kreditnya dan manajemen resiko sesuai dengan maksud dan tujuan peminjamnya.

Banyak faktor yang dapat mempengaruhi permintaan dan pemberian kredit oleh perbankan, bisa dari faktor bank itu sendiri seperti risk appetite terhadap suatu sektor, tingkat kredit macet, kurangnya modal, dan sebagainya ataupun juga faktor makro seperti tingkat suku bunga, nilai tukar rupiah, target ekspor dan faktor lainnya.

Oleh karena itu pemahaman yang baik mengenai pengaruh faktor - faktor tersebut khususnya faktor makro diharapkan dapat memberikan penjelasan mengenai dampak dari pergerakan indikator makro tersebut terhadap kredit di perbankan Indonesia yang terbagi menjadi tiga macam, yaitu : kredit modal kerja, kredit investasi, dan kredit konsumsi.

\section{PERUMUSAN MASALAH}

Sejalan dengan judul dan latar belakang diatas, maka permasalahan yang akan dibahas dalam penelitian ini adalah :

Apakah variabel - variabel makro seperti nilai tukar rupiah, tingkat suku bunga, dan jumlah ekspor dapat mempengaruhi jumlah kredit yang terbagi kedalam tiga jenis, yaitu kredit modal kerja, kredit investasi, dan kredit konsumsi?

\section{Tujuan Penelitian}

Sesuai dengan permasalahan yang diajukan, maka tujuan yang ingin dicapai dari penelitian ini adalah : Untuk membuktikan bahwa variabel - variabel makro seperti nilai tukar rupiah, tingkat suku bunga, dan jumlah ekspor tersebut dapat mempengaruhi jumlah kredit dan apakah memiliki pengaruh yang sama terhadap tiga macam kredit, yaitu kredit modal kerja, kredit investasi, dan kredit konsumsi 


\section{Manfaat Penelitian}

- Bagi perusahaan perbankan

Manfaat dari penelitian tersebut diharapkan nantinya dapat dipergunakan bagi pihak perusahaan perbankan sebagai bahan informasi dan masukan tambahan dalam pembuatan anggaran serta perencanaan strategis dalam menjalankan perusahaan di masa yang akan datang.

- Bagi Investor

Dan bagi pihak investor sendiri, diharapkan nantinya hasil dari penelitian tersebut bisa digunakan sebagai informasi tambahan untuk memperkirakan kinerja perbankan berdasarkan indikator-indikator makro yang ada.

- Bagi peneliti

Selain itu juga diharapkan penelitian tersebut bisa digunakan oleh peneliti sebagai media untuk mengaplikasikan teori yang di dapat dengan realisasi dinamika pada industri perbankan dan menguji apakah perubahan indikator makro seperti nilai tukar, tingkat suku bunga dan jumlah ekspor hanya berpengaruh terhadap golongan kredit tertentu saja atau berlaku umum.

\section{TINJAUAN TEORI}

Perekonomian di Indonesia pada tahun 2007 ini tumbuh 6.32\%, mencapai pertumbuhan tertinggi selama 5 tahun terakhir. Apa yang mendorong pertumbuhan perekonomian ini dapat dilihat dari 2 sisi yaitu: dari sisi produksi untuk mengetahui sektor sektor mana saja yang memberikan kontribusi terbesar pada pertumbuhan ekonomi, dan yang satu lagi adalah dilihat dari sisi pengeluaran yang dibagi menjadi tiga kelompok yaitu : investasi, ekspor dan konsumsi. Berdasarkan Jurnal Perkembangan Produk Domestik Bruto yang dapat dilihat dari website BI (http://www.bi.go.id/NR/rdonlyres/8EFDC99E-8888-4D63ADAC-B37F5BEC2039/9618/Tahun2007.pdf). Diketahui kontribusi terbesar untuk pertumbuhan ekonomi tahun 2007 ini adalah dari pengeluaran ekspor yaitu sebesar 3.77\% diikuti oleh komponen konsumsi dan investasi masing-masing sebesar 2.94\% dan $2.00 \%$.

Dengan alasan tersebut maka penelitian ini mengambil komponen ekspor dalam pemilihan salah satu variabel bebasnya disamping nilai tukar dan suku bunga yang menjadi indikator utama dalam segala bentuk analisis perekonomian. Pemilihan komponen ekspor sebagai salah satu variabel bebas didasarkan karena ekspor menjadi kontributor tertinggi dalam pertumbuhan perekonomian.

Hubungannya dengan kredit perbankan adalah dimana fungsi utama bank adalah sebagai lembaga intermediasi yang menyalurkan kredit kepada sektor riil agar perkonomian dapat tumbuh. Menggabungkan keduanya maka untuk memperkirakan jumlah kredit dalam penelitian ini maka peneliti menggunakan juga ekspor sebagai salah satu variabel bebasnya untuk melihat apakah ada hubungannya dengan pertumbuhan kredit bersama-sama dengan nilai tukar rupiah dan tigkat suku bunga.

Kata kredit berasal dari kata credere yang artinya "kepercayaan". Tujuan kredit dari pihak bank adalah untuk memperoleh keuntungan yang aman, sehingga pada saatnya masyarakat peminjam dana di bank dapat memperoleh kembali simpanannya berikut bunga tanpa dikuatirkan oleh adanya kredit macet. (Rimsky K, 2002). Fungsi kredit antara lain : 
- Meningkatkan daya guna uang

Para pemilik uang / modal baik secara langsung atau melalui penyimpanan dana di bank, dapat meminjamkan uangnya kepada perorangan atau perusahaan-perusahaan untuk meningkatkan usahanya

- Meningkatkan daya guna dan peredaran barang Dengan adanya kredit, pengusaha yang kesulitan dalam produksi, misalnya, dapat terbantu untuk memproses bahan baku menjadi barang jadi

- Meningkatkan peredaran dan lalu lintas uang Kredit uang yang disalurkan melalui rekening giro dapat menciptakan pembayaran dengan menggunakan uang giral seperti cek, bilyet giro, dan lainnya yang sejenis.

- Sebagai alat stabilitas ekonomi

Kredit dapat digunakan sebagai alat pengendalian ekonomi. Dalam keadaan inflasi pemerintah dapat menerapkan kebijakan uang ketat (tight money policy) antara lain dengan membatasi pemberian kredit. Sebaliknya dalam keadaan ekonomi yang lesu karena deflasi, pemerintah dapat melonggarkan kebijakan pemberian kredit sehingga akan menimbulkan kegiatan usaha.

- Meningkatkan kegairahan berusaha

Pihak - pihak yang usahanya terhambat karena kekurangan modal dapat meningkatkan usahanya melalui bantuan kredit yang diberikan oleh bank

- Meningkatkan pemerataan pendapatan

Dengan adanya kredit, perusahaan - perusahaan dapat meningkatkan usahanya bahkan dapat mendirikan proyek baru yang akan membutuhkan tenaga kerja.

- Meningkatkan hubungan international

Pengusaha di dalam negeri dapat pula memperoleh kredit baik secara langsung (offshore loan) maupun tidak langsung (two step loan).

\section{Kredit Dari Segi Penggunaannya}

Kredit bila dilihat dari segi penggunaannya dapat dibagi menjadi tiga, yaitu :

- Kredit Modal Kerja

Yaitu kredit berjangka waktu pendek yang diberikan oleh bank kepada perusahaan yang membutuhkan modal kerja untuk memperlancar kegiatan operasional perusahaan.

- Kredit Investasi

Kredit ini adalah kredit jangka menengah atau panjang yang diberikan oleh bank kepada pihak perusahaan yang membutuhkan dana untuk investasi atau penanaman modal.

- Kredit Konsumsi

Yaitu kredit yang diberikan dengan maksud untuk memperlancar kegiatan yang sifatnya konsumtif, seperti kredit pemilikan rumah, kredit pemilikan kendaraaan bermotor, credit card, dan kredit konsumtif lainnya. Jangka waktu kredit konsumsi ini bisa jangka pendek, menengah, maupun jangka panjang.

\section{Pengertian Suku Bunga}

Suku bunga adalah jumlah yang diterima oleh orang yang meminjamkan dan dibayar oleh peminjam dana sejumlah persentase yang disepakati oleh kedua belah pihak. (Subagyo,dkk, 2002). 
Suku bunga juga dapat dikelompokan menjadi suku bunga tetap dan suku bunga mengambang. Suku bunga tetap adalah suku bunga pinjaman tersebut tidak berubah sepanjang masa kredit, sedangkan suku bunga mengambang adalah suku bunga yang berubah-ubah selama masa kredit berlangsung dengan mengikuti suatu kurs referensi tertentu seperti misalnya $L I B O R$ dimana cara perhitungannya dengan menggunakan sistim penambahan marjin terhadap kurs referensi.

\section{Perubahan Suku Bunga}

Suku bunga dapat berubah bila salah satu dari demand or supply uang tidak lagi tercapai keseimbangan. Misalkan saat perekonomian memasuki tahap ekspansi dari suatu siklus bisnis dan meningkatkan juga Real Gross Domestic Product (GDP) maka akan meningkatkan transaksi keuangan yang akan mengakibatkan permintaan terhadap uang juga akan meningkat dimana supply nya tetap sama, dalam hal terjadi ketidakseimbangan ini maka interest rate akan bergerak agar tercapai kembali keseimbangan antara demand dan supply uang.

\section{Interest Rate Dan Pengeluaran Konsumsi}

Interest rate yang mengalami kenaikan dan penurunan membawa pengaruh terhadap pengeluaran konsumsi yang dilakukan oleh masyarakat.

Semakin rendah tingkat real interest rate maka semakin besar pula keinginan untuk berbelanja, karena tidak menariknya imbal balik yang dihasilkan oleh investasi.

\section{Interest Rate Dan Net Export}

Perubahan pada interest rate dapat merubah nilai ekspor bersih karena dengan asumsi semua sama, perubahan interest rate ternyata juga dapat mempengaruhi nilai tukar. Pada saat interest rate naik maka dana akan mengalir masuk untuk memanfaatkan kenaikan interest rate tersebut sehingga permintaan terhadap mata uang tersebut akan mengalami kenaikan dimana supplynya tetap sehingga akan menaikkan nilai tukar mata uang tersebut.

Pada saat interest rate suatu negara naik maka yang akan terjadi adalah akan berpengaruh terhadap kegiatan ekspor impor yang mana impor akan naik dan ekspor akan turun sehingga dapat mempengaruhi net ekspornya.

\section{Ekspor}

Ekspor adalah proses transportasi barang atau komoditas dari suatu negara ke negara lain secara legal, umumnya dalam proses perdagangan. Ekspor barang secara besar umumnya membutuhkan campur tangan dari bea cukai di negara pengirim maupun penerima. Ekspor adalah bagian penting dari perdagangan internasional, lawannya adalah impor. ( http://id.wikipedia.org/wiki/Ekspor)

Berdasarkan UU No. 10/95 Pasal 1 ayat 14, yang dimaksud dengan ekspor adalah kegiatan mengeluarkan barang dari daerah pabean. (W. Putu Gedhe Prawira, 2001)

Upaya mendorong ekspor dapat dimulai dengan melakukan berbagai kajian mengenai permasalahan ekspor. Pemahaman tentang permasalahan ekspor dapat ditindaklanjuti dengan berbagai upaya maupun kebijakan yang sesuai, sehingga hal ini diharapkan dapat menjadi stimulus untuk meningkatkan kinerja ekspor dan justru bukan menjadi distorsi bagi peningkatan ekspor. Identifikasi terhadap faktor-faktor pendukung dan penghambat ekspor merupakan langkah awal yang perlu dilakukan agar terjadi kesesuaian antara fasilitasi ekspor yang dilakukan oleh pemerintah dengan kebutuhan atau harapan para pelaku ekspor. 
Hasil analisis faktor terhadap faktor pendukung ekspor menghasilkan adanya 10 faktor, yaitu:

(1) promosi ekspor

(2) lembaga keuangan dan infrastruktur

(3) peraturan dan penegakannya

(4) peran pemerintah kepada eksportir

(5) kondisi internal perusahaan eksportir

(6) sarana transportasi laut dan udara domestik

(7) sarana telekomunikasi

(8) kondisi jalan

(9) kondisi moneter

(10) dukungan pelayanan pemerintah

Pandangan perbankan sebagai lembaga intermediasi keuangan, faktor-faktor yang dianggap sebagai pendukung ekspor antara lain adalah:

(1) keamanan dalam pembayaran

(2) memberikan modal kerja

(3) adanya kepastian jaminan pembayaran

(4) adanya korespondensi bank di luar negeri

(5) kondisi sosial, politik dan ekonomi.

Menurut perbankan, faktor penghambat dalam pelayanan aktivitas ekspor terutama meliputi kurang pahamnya eksportir tentang ekspor dan pembayaran lewat bank, kondisi ekonomi, regulasi pemerintah, dan kurangnya pemanfaatan jasa bank oleh eksportir, dan birokrasi kredit ekspor yang berbelit-belit.

\section{METODOLOGI}

Penelitian ini ditujukan untuk membuktikan apakah ada hubungan dan pengaruh dari tingkat suku bunga kredit, nilai tukar rupiah terhadap dollar Amerika, dan jumlah ekspor terhadap jumlah kredit perbankan. Dalam penelitian ini kredit perbankan yang digunakan adalah total kredit perbankan, kredit modal kerja, kredit investasi, kredit konsumsi. Setelah merumuskan masalah dan melakukan pembatasan ruang lingkup masalah yang diperlukan agar penelitian lebih terfokus, selanjutnya ditentukan model - model yang cocok dan metode metode analisis yang bisa digunakan untuk mencapai tujuan dari penelitian ini.

Selanjutnya dilakukan pengumpulan data, adapun data yang digunakan dalam penelitian ini adalah data kuartalan. Data yang diperlukan antara lain : data tingkat suku bunga yang diwakili oleh SBI 1 bulan, data nilai tukar rupiah terhadap dollar Amerika yang diwakili oleh kurs tengah nilai tukar rupiah terhadap USD, dan data ekspor untuk variabel bebasnya serta jumlah kredit, jumlah kredit modal kerja, jumlah kredit investasi, dan jumlah kredit konsumsi perbankan sebagai variabel terikat. Data yang diperoleh itu kemudian diolah, dimana untuk masing-masing data digunakan data kuartal dari periode Maret 2002 sampai dengan September 2007 (23 Periode).

Fungsi bank sebagai lembaga intermediasi yaitu menampung dana yang berlebih dan menyalurkan kepada yang kekurangan dana dalam bentuk kredit. Namun besarnya jumlah masyarakat Indonesia dan beragam latar belakang dan kekuatan ekonomi dan tujuan peminjaman kredit membuat bank-bank memiliki segmen nasabahnya sendiri yang berujung pada produk kredit yang sesuai dengan segmennya, umumnya segmen nasabah perbankan di 
Indonesia dibagi kedalam tiga garis besar yaitu Consumer Banking, Business Banking, dan Corporate Banking. Ketiga segmen ini memiliki karateristik terhadap produk kredit perbankan yang berbeda-beda, dan juga memiliki sensitivitas yang berbeda terhadap gejolak perekonomian. Dalam prakteknya setiap bank menyusun rencana kerja mereka setahun kedepan yang diantaranya terdapat target kredit, rencana ini dikirimkan awal tahun oleh setiap bank kepada bank sentral (Bank Indonesia), dalam penyusunannya proyeksi indikator makro yang menjadi asumsi Anggaran Pendapatan Belanja Negara (APBN) menjadi salah satu dasar oleh perbankan untuk memproyeksikan target kredit. Proyeksi yang akurat akan membuat pencapaian target yang baik di akhir tahun.

Namun perbedaan karakteristik nasabah yang beragam membuat bank mempunyai pengartian yang berbeda terhadap indikator makro dikaitkan dengan target pertumbuhan kredit yang terbagi menjadi tiga yaitu kredit modal kerja, investasi dan konsumsi. Oleh karena pemahaman yang baik antara hubungan indikator makro terhadap permintaan kredit sangat diperlukan, dan lebih dalam lagi adalah bagaimana pengaruh indikator makro tersebut permintaan kredit.

Penelitian akan dilakukan untuk menganalisis hubungan dan pengaruh antara :

1. Tingkat Suku Bunga Kredit, Nilai Tukar Rupiah Terhadap Dollar Amerika, Dan Jumlah Ekspor Terhadap Jumlah Kredit.

2. Tingkat Suku Bunga Kredit, Nilai Tukar Rupiah Terhadap Dollar Amerika, Dan Jumlah Ekspor Terhadap Jumlah Kredit Modal Kerja.

3. Tingkat Suku Bunga Kredit, Nilai Tukar Rupiah Terhadap Dollar Amerika, Dan Jumlah Ekspor Terhadap Jumlah Kredit Investasi.

4. Tingkat Suku Bunga Kredit, Nilai Tukar Rupiah Terhadap Dollar Amerika, Dan Jumlah Ekspor Terhadap Jumlah Kredit Konsumsi.

Analisis hubungan dan pengaruh antara variabel - variabel tersebut diatas akan diukur secara statistik dengan menggunakan metode korelasi dan regresi linier berganda serta uji hipotesis untuk mengambil kesimpulan ada atau tidak adanya hubungan yang signifikan. Kerangka pikir yang di gunakan dalam diagram alur pada gambar 1: 


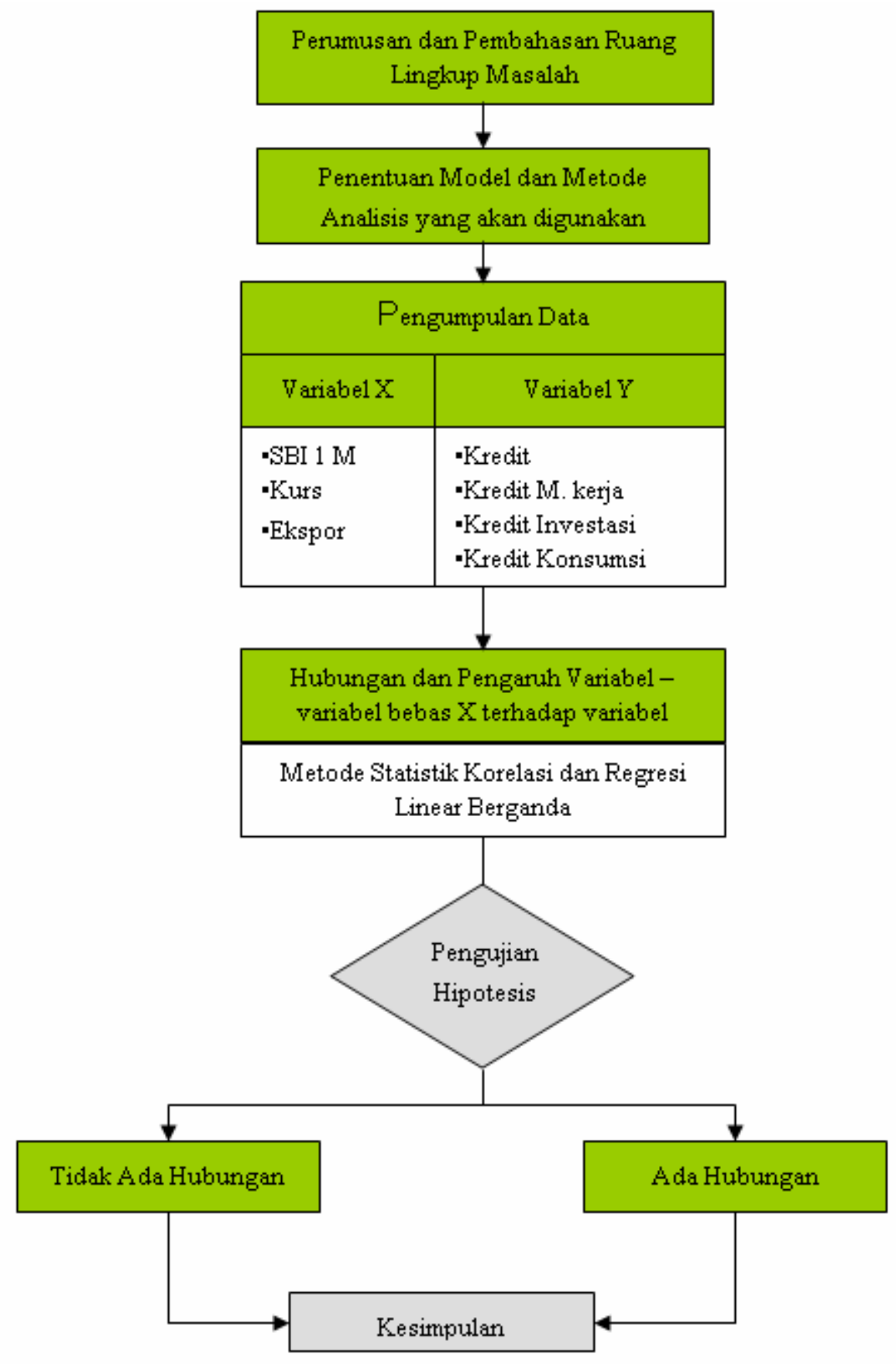

Gambar 1. Kerangka Pikir 


\section{MODEL DAN METODE ANALISIS}

Penulis menggunakan komponen - komponen ekspor, tingkat suku bunga, nilai tukar rupiah terhadap $U S D$, jumlah kredit, kredit modal kerja, kredit investasi, dan kredit konsumsi dalam model analisis, serta model statistik berupa pengujian hipotesis. Sedangkan metode analisis yang digunakan berupa analisis statistik dalam bentuk korelasi sederhana serta analisis regresi linier berganda. Penggunaan analisis - analisis tersebut dimaksudkan untuk mengetahui adanya atau tidak adanya hubungan antara variabel bebas (independent variabel) sebagai prediktor variabel dan dinotasikan sebagai variabel $\mathrm{X}$ terhadap variabel terikat/tak bebas (dependent variabel) sebagai hasil estimasi dan dinotasikan sebagai variabel $\mathrm{Y}$, serta besarnya pengaruh variabel $\mathrm{X}$ terhadap variabel $\mathrm{Y}$.

\section{Variabel Penelitian}

Variabel bebas yang di gunakan dalam penelitian ini adalah :

1. Ekspor

2. Tingkat Suku Bunga

3. Nilai Tukar Rupiah Terhadap USD

Sedangkan variabel terikat yang digunakan dalam penelitian ini adalah :

1. Jumlah Kredit

2. Jumlah Kredit Modal Kerja

3. Jumlah Kredit Investasi

4. Jumlah Kredit Konsumsi

Persamaan regresi berganda yang akan dibuat dalam penelitian ini adalah :

1. $\mathrm{X}_{1}=$ Ekspor; $\mathrm{X}_{2}=$ Tingkat suku bunga; $\mathrm{X}_{3}=$ Nilai tukar rupiah terhadap USD $\mathrm{Y}_{1}=$ Kredit

2. $\mathrm{X}_{1}=$ Ekspor; $\mathrm{X}_{2}=$ Tingkat suku bunga; $\mathrm{X}_{3}=$ Nilai tukar rupiah terhadap $U S D$ $\mathrm{Y}_{2}=$ Kredit Modal Kerja

3. $\mathrm{X}_{1}=$ Ekspor; $\mathrm{X}_{2}=$ Tingkat suku bunga; $\mathrm{X}_{3}=$ Nilai tukar rupiah terhadap $U S D$ $\mathrm{Y}_{3}=$ Kredit Investasi

4. $\mathrm{X}_{1}=$ Ekspor; $\mathrm{X}_{2}=$ Tingkat suku bunga; $\mathrm{X}_{3}=$ Nilai tukar rupiah terhadap USD $\mathrm{Y}_{4}=$ Kredit Konsumsi

\section{Metode Pengumpulan Data}

Penelitian dilakukan dengan menggunakan data dalam rentang waktu 23 (Dua Puluh Tiga) kuartal yaitu dari Maret 2002 sampai dengan September 2007. Pergerakan indikator makro ekonomi Indonesia bervariasi, sehingga pergerakan perubahannya dapat mencerminkan volatilitas perekonomian. Pos yang dijadikan obyek penelitian adalah jumlah kredit, jumlah kredit modal kerja, jumlah kredit investasi, dan jumlah kredit konsumsi dari seluruh perbankan di Indonesia.

\section{Sumber Data Penelitian}

1. Tingkat suku bunga

Tingkat suku bunga kredit adalah tingkat suku bunga yang diwakili oleh nilai SBI 1 bulan yang menjadi patokan untuk suku bunga dana, data diambil kuartalan yang di peroleh dari website Bank Indonesia (www.bi.go.id)

2. Nilai tukar rupiah terhadap USD 
Data nilai tukar rupiah terhadap USD yang digunakan adalah berdasarkan data nilai penutupan rupiah per 1 USD menurut Bank Indonesia (kurs BI) pada setiap akhir kuartal yang di peroleh dari website Bank Indonesia (www.bi.go.id)

3. Jumlah Ekspor

Adalah jumlah ekspor untuk setiap kuartal, yang diperoleh dari website Bank Indonesia (www.bi.go.id)

\section{Hipotesis}

Tabel 1. Hipotesis

\begin{tabular}{|c|l|}
\hline Hipotesis & \multicolumn{1}{|c|}{ Deskripsi Hipotesis Penelitian } \\
\hline $\mathrm{H}_{0} 1$ & Hubungan antara Ekspor terhadap Kredit tidak signifikan \\
\hline $\mathrm{H}_{0} 2$ & Hubungan antara Tingkat Suku Bunga terhadap Kredit tidak signifikan \\
\hline $\mathrm{H}_{0} 3$ & Hubungan antara Kurs terhadap Kredit tidak signifikan \\
\hline $\mathrm{H}_{0} 4$ & $\begin{array}{l}\text { Hubungan antara Ekspor, Tingkat Suku Bunga, dan Kurs secara bersama-sama } \\
\text { terhadap Kredit tidak signifikan }\end{array}$ \\
\hline
\end{tabular}

\section{Metode Analisis}

\section{Teknik Statistik Dalam Analisis Hubungan}

Teknik statistik yang digunakan dalam analisis hubungan meliputi perhitungan Korelasi (koefisien korelasi), dan analisis Regresi Berganda dikarenakan ada variabel bebas yang lebih dari satu serta uji statistiknya masing masing dan koefisien determinasi.

1. Koefisien Korelasi

Koefisien korelasi adalah indeks bilangan yang digunakan untuk mengukur derajat hubungan, meliputi kekuatan hubungan dan bentuk / arah hubungan.

Rumusan korelasi Pearson Product Moment adalah sebagai berikut :

$$
r=\frac{n \cdot \sum X_{i} \cdot Y_{i}-\sum X_{i} \cdot \sum Y_{i}}{\sqrt{n \cdot \sum X_{i}^{2}-\left(\sum X_{i}\right)^{2}} \cdot \sqrt{n \cdot \sum Y_{i}^{2}-\left(\sum Y_{i}\right)^{2}}}
$$

$$
\text { Dimana: } \begin{aligned}
r & =\text { Koefisien Korelasi } \\
\mathrm{X}_{\mathrm{i}} & =\text { Nilai Variabel Bebas } \\
\mathrm{Y}_{\mathrm{i}} & =\text { Nilai Variabel Tidak Bebas }
\end{aligned}
$$

Untuk mengetahui adanya atau tidak adanya hubungan antara suatu variabel (variabel $\mathrm{X}$ ) dengan variabel lainnya (variabel $\mathrm{Y}$ ), dapat dilakukan melalui pengujian hipotesis, yaitu :

$$
\begin{aligned}
& \mathrm{H}_{0}: \rho=0 \text { (Tidak ada hubungan antara variabel } \mathrm{X} \text { dan variabel } \mathrm{Y} \text { ). } \\
& \mathrm{H}_{1}: \rho \neq 0 \text { (Ada hubungan antara variabel } \mathrm{X} \text { dan variabel } \mathrm{Y} \text { ). }
\end{aligned}
$$

Dimana statistik uji (test statistic) yang digunakan dapat dirumuskan sebagai berikut : 


$$
t_{(n-2)}=\frac{r}{\sqrt{\left(1-r^{2}\right) /(n-2)}}
$$

Hasil dari statistik uji ini kemudian dibandingkan dengan $t_{(\alpha / 2, n-2)}$ dan nilai yang dapat dilihat pada tabel distribusi t.

2. Regresi Linier Berganda (Multiple Regression)

Model regresi linier sederhana mencakup dua parameter, yaitu intercept parameter yang di notasikan dengan $\beta_{0}$, dan slope parameter yang dinotasikan dengan $\beta_{1}$. Rumusan untuk regresi linier sederhana, adalah :

$$
\mathrm{Y}=\beta_{0}+\beta_{1} \mathrm{X}+\varepsilon
$$

Dimana :

$\mathrm{Y}=$ Variabel terikat (dependent variabel)

$\beta_{0}=$ Konstanta (intercept parameter)

$\beta_{1} \mathrm{X}=$ Slope variabel bebas (independent variabel)

$\varepsilon \quad=$ Standard Error

Interval keyakinan (confidence interval) yang terdapat digunakan adalah $\mathrm{t}_{(\alpha / 2, \mathrm{n}-2)}$, dengan nilai yang dapat dilihat pada tabel distribusi t. Derajat bebas (degree of freedom) untuk mengetahui kesalahan dalam regresi sederhana dinyatakan dengan $n-2$ karena dari jumlah $n$ data di mana hanya ada dua parameter $\left(\beta_{0}\right.$ dan $\left.\beta_{1}\right)$ akan diperkirakan.

Untuk mengetahui adanya atau tidak adanya hubungan linier antara suatu variabel (variabel X) dengan variabel lainnya (variabel Y) dapat dilakukan melalui pengujian hipotesis (hypothesis testing) yang merupakan pengujian dua arah (two tailed test), yaitu :

$\mathrm{H}_{0}: \beta_{1}=0$ (tidak ada hubungan linier antara variabel $\mathrm{X}$ dan variabel $\mathrm{Y}$ )

$\mathrm{H}_{1}: \beta_{1} \neq 0$ (ada hubungan linier antara variabel $\mathrm{X}$ dan variabel $\mathrm{Y}$ )

Statistik uji (statistic test) yang digunakan dapat dirumuskan sebagai berikut :

$$
t_{(n-2)}=\frac{b_{1}}{s\left(b_{1}\right)}
$$

Dimana :

$\mathrm{t}_{(\mathrm{n}-2)}=$ Distribusi $\mathrm{t}$ dengan derajat bebas (degree of freedom) adalah $\mathrm{n}-2$

$\mathrm{b}_{1} \quad$ = Penduga parameter

$\mathrm{s}\left(\mathrm{b}_{1}\right)=$ Standard error dari penduga parameter.

Bilamana pengujian hipotesis dilakukan untuk melihat adanya atau tidak adanya hubungan dan pengaruh antara beberapa variabel variabel bebas sebagai predikator variables (variabel X) dengan variabel terikat sebagai hasil estimasi (variabel Y), maka teknik regresi yang dilakukan merupakan regresi berganda (multiple regression), dengan rumusan sebagai berikut :

Dimana :

$$
\mathrm{Y}=\beta_{0}+\beta_{1} \mathrm{X}_{1}+\beta_{2} \mathrm{X}_{2}+\beta_{3} \mathrm{X}_{3}+\ldots+\beta_{\mathrm{i}} \mathrm{X}_{\mathrm{i}}+\varepsilon
$$

$\mathrm{Y}=$ Variabel terikat (dependent variabel)

$\beta_{0}=$ Konstanta (intercept parameter)

$\beta_{\mathrm{i}} \mathrm{X}_{\mathrm{i}}=$ Slope variabel bebas ke $\mathrm{i}$

$\varepsilon \quad=$ Standard error 
Mengingat adanya lebih dari satu slope variabel bebas, maka pengujian statistik yang dapat di gunakan adalah $F$-test dengan jumlah derajat bebas adalah n-1, dan derajat bebas untuk error adalah $\mathrm{n}-(\mathrm{k}+1)$.

Sedangkan untuk melakukan pengujian hipotesis, dapat dirumuskan sebagai berikut : $\mathrm{H}_{0}: \beta_{1}=\beta_{2}=\ldots=\beta_{\mathrm{i}}=0$ ( tidak ada hubungan antara variabel variabel $\mathrm{X}$ dan $\mathrm{Y}$ ) $\mathrm{H}_{1}: \beta_{\mathrm{i}} \neq 0$ ( ada hubungan antara sedikitnya satu variabel $\mathrm{X}$ dan variable $\mathrm{Y}$ )

Untuk melihat besarnya pengaruh explanatory power masing masing variabel $\mathrm{X}_{\mathrm{i}}$ (variabel bebas) terhadap variabel Y ( hasil estimasi) dapat dilakukan pengujian signifikansi parameter slope regresi individu(test of the significance of individual regression slope parameter) $\beta_{\mathrm{i}}$, dengan rumus :

$$
t_{[n-(k+1)]}=\frac{b_{i}-0}{s\left(b_{j}\right)}
$$

Dimana :

$\mathrm{t}_{[\mathrm{n}-(\mathrm{k}+1)]}=$ Distribusi $\mathrm{t}$ dengan derajat bebas adalah $\mathrm{n}-(\mathrm{k}+1)$

$\mathrm{b}_{\mathrm{i}} \quad=$ Penduga parameter ke $\mathrm{i}$

$\mathrm{s}\left(\mathrm{b}_{\mathrm{i}}\right)=$ Standard error dari penduga parameter ke - $\mathrm{i}$.

\section{Koefisien Determinasi}

Untuk regresi linier berganda, koefisien determinasi yang lebih baik digunakan adalah adjustment koefisien determinasi yang telah dikoreksi dengan derajat bebas untuk error. Rumusan adjustment koefisien determinasi adalah sebagai berikut :

$$
\overline{\mathrm{R}}^{2}=1-\left(1-\mathrm{R}^{2}\right)\left[\frac{(\mathrm{n}-1)}{\mathrm{n}-(\mathrm{k}+1)}\right]
$$

Dimana :

$\mathrm{R}^{2} \quad=$ Koefisien determinasi

$\mathrm{n}-1=$ Derajat bebas

$\mathrm{n}-(\mathrm{k}+1)=$ Derajat bebas untuk error

\section{Uji Hipotesis}

Dalam pengujian hipotesis ada beberapa langkah yang harus dilalui yang dikenal dengan prosedur pengujian hipotesis, yaitu sebagai berikut :

a. Menentukan Formulasi Hipotesisnya

- Hipotesis nol $\left(\mathrm{H}_{0}\right)$

- Hipotesis alternatif $\left(\mathrm{H}_{1}\right)$

b. Menentukan Taraf Kesalahan dan Tingkat Kepercayaan

Taraf kesalahan adalah batas toleransi dalam menerima kesalahan dari hasil hipotesis terhadap nilai parameter populasinya. Suatu kesimpulan dari data sampel yang akan diberlakukan untuk populasi mempunyai peluang kesalahan dan kebenaran (kepercayaan ) yang dinyatakan dalam bentuk prosentase. Jika peluang kesalahan $5 \%$, maka tingkat kepercayaan 95\%. Peluang kesalahan dan tingkat kepercayaan ini disebut level of significant atau tingkat signifikansi. Suatu hipotesis dengan taraf kesalahan $1 \%$ berarti jika 
penelitian dilakukan pada 100 sampel yang diambil dari populasi yang sama, akan terdapat satu kesimpulan yang salah yang diberlakukan untuk populasi.

Dalam penelitian ini, peneliti menggunakan taraf kesalahan 5\% dan tingkat kepercayaan $95 \%$

c. Menentukan Kriteria Pengujian

Kriteria pengujian adalah bentuk pembuatan keputusan dalam hal tidak menolak atau menolak hipotesis nol dengan cara membandingkan nilai kritis (nilai $\alpha$ tabel dari distribusinya) dengan nilai uji statistiknya.

- Hipotesis nol $\left(\mathrm{H}_{0}\right)$ tidak ditolak jika nilai uji statistiknya berada diluar nilai-nilai kritisnya.

- Hipotesis nol $\left(\mathrm{H}_{0}\right)$ ditolak jika nilai uji statistiknya berada diluar nilai nilai kritisnya.

d. Melakukan Uji Statistik

Uji statistik ini merupakan rumus - rumus dari distribusi (berhubungan dengan distribusi) tertentu, seperti Uji - $\mathrm{t}$ (distribusi t) untuk regresi sederhana dan uji F untuk regresi berganda. Pengujian hipotesis dapat dibagi menjadi 2 (dua), yaitu :

1. Pengujian Hipotesis dengan Uji - $\mathrm{t}$ Untuk menguji hipotesis ada atau tidaknya pengaruh variabel bebas secara parsial terhadap variabel terikat akan digunakan Uji-t, yaitu dengan membandingkan signifikansi t-hitung ( $p$-value) dan signifikansi t-tabel dengan tingkat kepercayaan $95 \%(\alpha=5 \%)$.

- Jika p-value $<0.01$ berarti variabel bebas tersebut berpengaruh sangat signifikan terhadap variabel terikat.

- Jika $p$-value $<0.05$ berarti variabel bebas tersebut berpengaruh signifikan terhadap variabel terikat.

- Jika $p$-value $>0.05$ berarti variabel bebas tersebut berpengaruh tidak signifikan terhadap variabel terikat.

2. Pengujian Hipotesis dengan Uji F

Untuk menguji ada tidaknya pengaruh signifikan antara beberapa variabel bebas secara bersama-sama terhadap variabel terikat, maka akan digunakan Uji-F, yaitu dengan membandingkan signifikansi F-hitung ( $p$-value) dan signifikansi F-tabel dengan tingkat kepercayaan $95 \%$

- Jika $p$-value $<0.01$ berarti variabel bebas tersebut berpengaruh sangat signifikan terhadap variabel terikat.

- Jika $p$-value $<0.05$ berarti variabel bebas tersebut berpengaruh signifikan terhadap variabel terikat.

- Jika $p$-value $>0.05$ berarti variabel bebas tersebut berpengaruh tidak signifikan terhadap variabel terikat.

e. Membuat Kesimpulan

Pembuatan kesimpulan ini merupakan penetapan keputusan dalam hal tidak menolak atau menolak hipotesis nol sesuai dengan kriteria pengujian.

\section{Uji Validitas Model Regresi Linier}

Terdapat 4 uji validitas yang harus dilakukan untuk menentukan apakah model regresi yang terbentuk memenuhi kriteria-kriteria yang ditetapkan untuk model tersebut.

1. Uji Multikolinearitas. 
Uji multikolinearitas hanya digunakan untuk regresi berganda, dimana tujuannya adalah untuk melihat apakah pada model regresi ditemukan adanya korelasi antara variabel-variabel bebas. Jika terjadi korelasi, maka dapat dikatakan terjadi gejala multikolinearitas. Model regresi yang baik seharusnya antara variabel bebasnya tidak terjadi korelasi. Pengujian ada tidaknya gejala multikolinearitas dilakukan dengan melihat besaran Variance Inflation Factor (VIF).

Suatu model regresi yang bebas multikolinearitas adalah mempunyai VIF dibawah 2. Jika terdapat VIF diatas 2, maka antar variabel independent terjadi multikolinearitas.

Apabila model prediksi memiliki multikolinearitas akan mengakibatkan antara lain :

- Varian dan kovarian akan besar sehingga sulit dijadikan alat estimasi

- Interval estimasi cenderung lebar dan nilai statistik uji-t akan kecil, sehingga menyebabkan variabel independent tidak signifikan secara statistik dalam mempengaruhi variabel independent.

Salah satu cara untuk mengatasi masalah multikolinearitas adalah dengan menggunakan metode stepwise, dimana metode ini dimulai dengan memasukkan variabel bebas yang memiliki korelasi paling kuat dengan variabel terikat. Kemudian setiap kali pemasukan variabel bebas yang lain, dilakukan pengujian untuk tetap memasukkan variabel bebas atau mengeluarkannya. Metode stepwise akan menghasilkan persamaan regresi yang relatif bebas gejala multikolinearitas dan memiliki tingkat kepercayaan yang dipersyaratkan terhadap seluruh variabel bebasnya serta memiliki adjustment $R$ square yang lebih tinggi.

2. Uji Heteroskedastisitas

Uji ini bertujuan untuk melihat apakah dalam sebuah model regresi terjadi ketidaksamaan varians residual dari satu pengamatan ke pengamatan yang lain. Model regresi yang baik akan meninggalkan residu (error) yang diasumsikan terdistribusi normal, yang tidak saling berkorelasi (berhubungan) atau tidak menunjukkan pola tertentu.

Untuk menguji apakah model mengandung heteroskedastis atau tidak dapat menggunakan salah satunya adalah uji white. Uji white ini menggunakan residual kuadrat sebagai variabel terikat, dan variabel bebasnya terdiri atas variabel bebas yang sudah ada, ditambah dengan kuadrat variabel bebas, ditambah lagi dengan perkalian dua variabel bebas.

Bila model memiliki variabel residu yang heteroskedastis maka akan mengakibatkan antara lain :

- Estimator metode kuadrat terkecil tidak mempuyai varian yang minimum (tidak lagi best), sehingga hanya memenuhi karakteristik linear unbiased estimator $(L U E)$. Meskipun demikian, estimator metode kuadrat terkecil masih bersifat linear dan tidak bias.

- Perhitungan standard error tidak dapat lagi dipercaya kebenarannya, karena varian tidak minimum. Varian yang tidak minimum mengakibatkan estimasi regresi tidak efisien

- Uji hipotesis yang didasarkan pada Uji t dan Uji F tidak dapat lagi dipercaya, karena standard error-nya tidak dapat dipercaya. 


\section{Uji Autokorelasi}

Pengujian autokorelasi dilakukan untuk menguji apakah dalam model regresi linear terdapat korelasi antara data residu (error) periode tertentu dengan data residu periode sebelumnya. Jika terjadi gejala korelasi maka terjadi masalah autokorelasi. Model regresi yang baik adalah regresi yang bebas dari autokorelasi. Pengujian autokorelasi dilakukan dengan memperhatikan uji test statistik Durbin Watson, yaitu dengan menggunakan rumus sebagai berikut :

$$
d=\frac{\sum_{i=2}^{n}\left(e_{i}-e_{i-1}\right)^{2}}{\sum_{i=1}^{n} e_{i}^{2}}
$$

Dimana :

d = Hasil uji statistik Durbin Watson

$\mathrm{e}_{\mathrm{i}}=$ Residu pada posisi ke- $\mathrm{i}$

$\mathrm{e}_{\mathrm{i}-1}=$ Residu pada posisi ke i-1

Hasil uji test statistik Durbin Watson akan dibandingkan dengan kritikal poin dari tabel Critical Values of Durbin Watson Test Statistic for $\alpha=0.05$. Hasil kesimpulan ada atau tidak adanya autokorelasi dapat dijelaskan sebagai berikut :

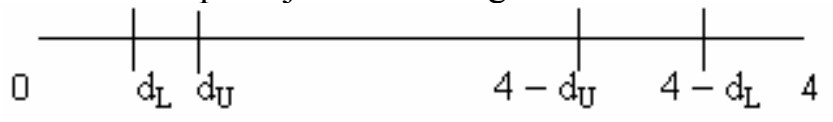

- Jika nilai Durbin Watson berada di antara $0 \mathrm{~s} / \mathrm{d} \mathrm{d}_{\mathrm{L}}$, maka terjadi autokorelasi positif

- Jika nilai Durbin Watson berada di antara $\mathrm{d}_{\mathrm{U}}$ dan $4-\mathrm{d}_{\mathrm{U}}$, maka tidak terjadi autokorelasi

- Jika nilai Durbin Watson berada di antara $4-\mathrm{d}_{\mathrm{L}}$ dan 4 , maka terjadi autokorelasi negatif

- Jika nilai Durbin Watson berada di antara $\mathrm{d}_{\mathrm{L}}$ dan $\mathrm{d}_{\mathrm{U}}$ atau $4-\mathrm{d}_{\mathrm{U}}$ dan $4-\mathrm{d}_{\mathrm{L}}$ maka tidak dapat diambil kesimpulan apakah terjadi autokorelasi atau tidak.

Model yang memiliki autokorelasi, maka estimatornya akan memiliki karakteristik seperti berikut :

- Estimator metode kuadrat terkecil masih linear

- Estimator metode kuadrat terkecil masih tidak bias

- Estimator metode kuadrat terkecil tidak mempunyai varian minimum

Dengan demikian, seperti halnya pengaruh heteroskedastisitas, autokorelasi juga akan menyebabkan estimator bersifat $L U E$, tidak lagi $B L U E$.

4. Uji Normalitas

Uji Normalitas dilakukan untuk mengetahui apakah distribusi residual memiliki distribusi yang normal. Untuk mengetahui suatu residual memiliki distribusi yang normal 
atau tidak dapat menggunakan Histogram, dan bila bentuknya menyerupai garis lonceng maka artinya data tersebut berdistribusi normal.

\section{ANALISA DAN PEMBAHASAN}

Sebagai alat bantu analisis digunakan software MS Excel 2003 dan software SPSS ver 16., untuk mengetahui hubungan dan pengaruh hubungan antara ekspor, tingkat suku bunga dan kurs rupiah terhadap USD (selanjutnya disebut "kurs" saja) yang digunakan sebagai variabel bebas dengan jumlah kredit menjadi variabel terikat, adapun kredit sendiri dibagi lagi kedalam tiga kelompok yaitu kredit modal kerja, kredit investasi, dan kredit konsumsi.

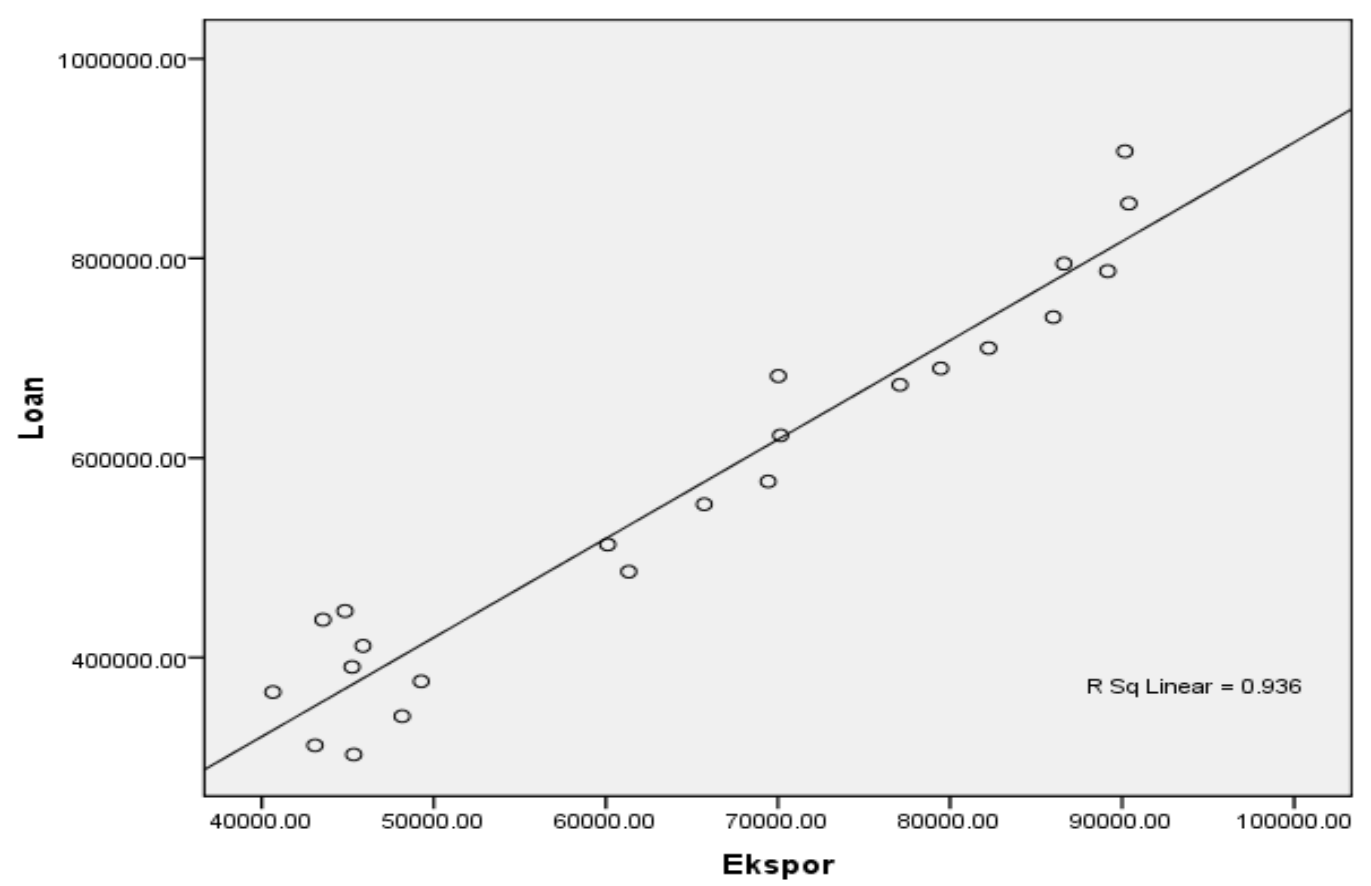

Gambar 2. Analisis Hubungan Linear Yang Terjadi Antara Varibel Bebas X Dengan Variabel Terikat Y

Dari gambar dapat dikatakan bahwa nilai ekspor memiliki hubungan linier dengan jumlah kredit. Dengan metode yang sama, dilakukan analisis untuk masing-masing variabel bebas $\mathrm{X}$ terhadap variabel terikat Y. Hasil dapat dilihat pada lampiran B.

Analisis Menggunakan Matrik Korelasi Untuk Melihat Arah Dan Hubungan Antara Variabel - Variabel.

Matrik korelasi digunakan untuk melihat hubungan antara variabel-variabel yang terlibat baik arah dan hubungannya, nilai sempurna dari korelasi adalah -1 dan 1 , dimana untuk -1 menunjukkan hubungan berlawanan yang sempurna dimana jika salah satu nilai variabel naik maka nilai variabel lainnya turun, begitu juga dengan korelasi dengan nilai satu tetapi perbedaanya adalah arahnya tidak berlawanan, sehingga saat satu nilai variabel naik 
maka nilai variabel lainnya juga ikut naik. Dengan bantuan SPSS akan dihitung matrik korelasi antar variabel dengan menggunakan metode Pearson.

Tabel 2. Correlations

\begin{tabular}{|ll|l|l|l|l|}
\hline & & Loan & Ekspor & BI_Rate & Kurs \\
\hline Loan & Pearson Correlation & 1 & $.968^{* *}$ & -.325 & .357 \\
& Sig. (2-tailed) & & .000 & .130 & .095 \\
& $\mathrm{~N}$ & 23 & 23 & 23 & 23 \\
\hline Ekspor & Pearson Correlation & $.968^{* *}$ & 1 & -.230 & $.488^{*}$ \\
& Sig. (2-tailed) & .000 & & .291 & .018 \\
& $\mathrm{~N}$ & 23 & 23 & 23 & 23 \\
\hline BI_Rate & Pearson Correlation & -.325 & -.230 & 1 & .120 \\
& Sig. (2-tailed) & .130 & .291 & & .587 \\
& $\mathrm{~N}$ & 23 & 23 & 23 & 23 \\
\hline Kurs & Pearson Correlation & .357 & $.488^{*}$ & .120 & 1 \\
& Sig. (2-tailed) & .095 & .018 & .587 & \\
& $\mathrm{~N}$ & 23 & 23 & 23 & 23 \\
\hline
\end{tabular}

**. Correlation is significant at the 0.01 level (2-tailed).

*. Correlation is significant at the 0.05 level (2-tailed).

\section{Tabel Matrik Korelasi Untuk Masing - Masing Variabel Bebas Terhadap Kredit}

Dari tabel dapat disimpulkan sebagai berikut, bahwa menurut korelasi dengan metode Pearson bahwa hubungan antara ekspor dengan kredit berhubungan positif dengan korelasi sebesar $96.8 \%$, hubungan tingkat suku bunga dengan kredit mempunyai hubungan negatif dengan korelasi sebesar $32.5 \%$ dan hubungan kurs dengan kredit mempunyai hubungan positif sebesar $35.7 \%$. Selanjutnya dilakukan perhitungan juga untuk variabel lainnya yang dapat disimpulkan bahwa hubungan antara ekspor dengan kredit investasi berhubungan positif dengan korelasi sebesar $96 \%$, hubungan tingkat suku bunga dengan kredit investasi mempunyai hubungan negatif dengan korelasi sebesar $40.1 \%$ dan hubungan kurs dengan kredit investasi mempunyai hubungan positif sebesar 36.2\%. Dan hubungan antara ekspor dengan kredit konsumsi berhubungan positif dengan korelasi sebesar 96.5\%, hubungan tingkat suku bunga dengan kredit konsumsi mempunyai hubungan negatif dengan korelasi sebesar $31.2 \%$ dan hubungan kurs dengan kredit konsumsi mempunyai hubungan positif sebesar $38.6 \%$.

\section{Analisis Regresi Linear Berganda}

Analisis Regresi Linear Berganda Untuk Variabel Ekspor, Tingkat Suku Bunga Dan Kurs Terhadap Kredit. 
Tabel 3. ANOVA ${ }^{\mathrm{b}}$

\begin{tabular}{|c|c|c|c|c|c|c|}
\hline \multicolumn{2}{|c|}{ Model } & \begin{tabular}{|l} 
Sum \\
Squares
\end{tabular} & Df & Mean Square & $\mathrm{F}$ & Sig. \\
\hline \multirow[t]{3}{*}{1} & Regression & $7.205 \mathrm{E} 11$ & 3 & 2.402E11 & 148.117 & $.000^{\circ}$ \\
\hline & Residual & $3.081 \mathrm{E} 10$ & 19 & $1.621 \mathrm{E} 9$ & & \\
\hline & Total & 7.513E11 & 22 & & & \\
\hline
\end{tabular}

a. Predictors: (Constant), Ekspor, BI_Rate, Kurs

b. Dependent Variable: Loan

Dari tabel ANOVA dapat dilihat bahwa untuk model regresi untuk variabel bebas $\mathrm{X}$, yaitu ekspor, tingkat suku bunga, dan kurs secara bersama-sama dapat menjelaskan tidak secara kebetulan adanya pengaruh yang signifikan terhadap kredit, yaitu dengan nilai signifikansi sebesar 0.000 atau dibawah 0.05 .

Dengan bantuan software SPSS dihasilkan tabel summary kredit yang berisikan informasi antara lain adjusted $R$ Square

Tabel 4. Model Summary ${ }^{\mathrm{b}}$

\begin{tabular}{|l|l|l|l|l|l|}
\hline Model & $R$ & $R$ Square & $\begin{array}{l}\text { Adjusted } \\
\text { Square }\end{array}$ & $\begin{array}{l}\text { Std. Error of } \\
\text { the Estimate }\end{array}$ & Durbin-Watson \\
\hline 1 & $.979^{\mathrm{a}}$ & .959 & .953 & 40267.67678 & 1.621 \\
\hline
\end{tabular}

a. Predictors: (Constant), Ekspor, BI_Rate, Kurs

b. Dependent Variable: Loan

dapat diketahui informasi mengenai persentase penjelasan hubungan antara variabel bebas dengan variabel terikat dengan melihat kepada adjusted $R$ Square, untuk persamaan regresi dengan variabel bebas $\mathrm{X}_{1}=$ ekspor, $\mathrm{X}_{2}=$ tingkat suku bunga, $\mathrm{X}_{3}=$ kurs terhadap $\mathrm{Y}_{1}=$ kredit, dapat disimpulkan bahwa sebesar $95.3 \%$ perubahan pada kredit dapat dijelaskan oleh perubahan-perubahan oleh variabel ekspor, tingkat suku bunga dan kurs sedangkan $4.7 \%$ disebabkan oleh faktor lainnya.

Signifikansi antara masing - masing variabel bebas $\mathrm{X}$ terhadap variabel terikat $\mathrm{Y}$

Tabel 5. Coefficients Untuk Ekspor, Tingkat Suku Bunga, dan Kurs Kredit Coefficients ${ }^{\mathrm{a}}$

\begin{tabular}{|c|c|c|c|c|c|c|c|}
\hline \multirow[b]{2}{*}{ Model } & \multicolumn{2}{|c|}{$\begin{array}{l}\text { Unstandardized } \\
\text { Coefficients }\end{array}$} & \multirow{2}{*}{$\begin{array}{l}\text { Standardized } \\
\text { Coefficients } \\
\text { Beta }\end{array}$} & \multirow[b]{2}{*}{ It } & \multirow[b]{2}{*}{ Sig. } & \multicolumn{2}{|c|}{ Collinearity Statistics } \\
\hline & B & Std. Error & & & & Tolerance & VIF \\
\hline $1 \quad$ (Constant) & 398764.236 & 173452.874 & & 2.299 & .033 & & \\
\hline BI_Rate & -5278.078 & 3386.992 & -.077 & -1.558 & .136 & .877 & 1.141 \\
\hline Kurs & -49.305 & 21.342 & -.128 & -2.310 & .032 & .705 & 1.418 \\
\hline Ekspor & 10.385 & .579 & 1.012 & 17.936 & .000 & .678 & 1.476 \\
\hline
\end{tabular}

a. Dependent Variable: Loan

Summary kredit mengenai signifikansi masing - masing variabel bebas $\mathrm{X}$ maupun secara bersama - sama dapat dilihat 
Tabel 6. Summary Signifikansi

\begin{tabular}{|c|l|c|c|}
\hline Hipotesis & \multicolumn{1}{|c|}{ Deskripsi Hipotesis Penelitian } & Hasil & $\begin{array}{c}\text { Signifikansi } \\
\text { (hasil }<\mathbf{0 . 0 5})\end{array}$ \\
\hline $\mathrm{H}_{0} 1$ & $\begin{array}{l}\text { Hubungan antara Ekspor terhadap Kredit tidak } \\
\text { signifikan }\end{array}$ & 0.000 & Signifikan \\
\hline $\mathrm{H}_{0} 2$ & $\begin{array}{l}\text { Hubungan antara Tingkat Suku Bunga } \\
\text { terhadap Kredit tidak signifikan }\end{array}$ & 0.136 & Tidak Signifikan \\
\hline $\mathrm{H}_{0} 3$ & $\begin{array}{l}\text { Hubungan antara Kurs terhadap Kredit tidak } \\
\text { signifikan }\end{array}$ & 0.032 & Signifikan \\
\hline $\mathrm{H}_{0} 4$ & $\begin{array}{l}\text { Hubungan antara Ekspor, Tingkat Suku Bunga, } \\
\text { dan Kurs secara bersama-sama terhadap Kredit } \\
\text { tidak signifikan }\end{array}$ & 0.000 & Signifikan \\
\hline
\end{tabular}

\section{Uji Asumsi Regresi Linear Kredit}

Uji Normalitas

\section{Histogram}

\section{Dependent Variable: Loan}

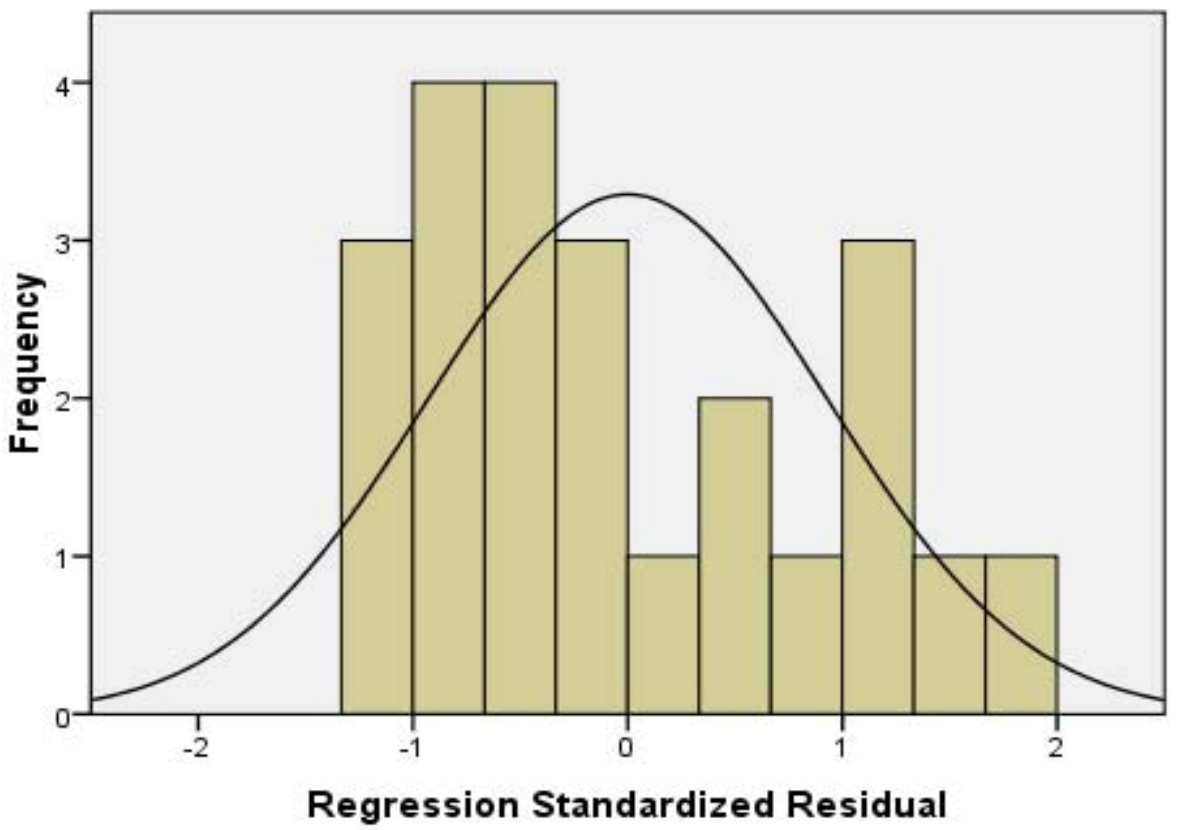

Mean $=-9.99 \mathrm{E}-16$ Std. Dev. $=0.929$ $N=23$

Gambar 3. Histogram Untuk Residual Kredit 
Uji Multikolinearitas

Tabel 7. Coefficients ${ }^{\mathrm{a}}$

\begin{tabular}{|c|c|c|c|c|c|c|c|}
\hline \multirow[b]{2}{*}{ Model } & \multicolumn{2}{|c|}{$\begin{array}{l}\text { Unstandardized } \\
\text { Coefficients }\end{array}$} & \multirow{2}{*}{\begin{tabular}{|l}
$\begin{array}{l}\text { Standardized } \\
\text { Coefficients }\end{array}$ \\
Beta
\end{tabular}} & \multirow[b]{2}{*}{ It } & \multirow[b]{2}{*}{ Sig. } & \multicolumn{2}{|c|}{ Collinearity Statistics } \\
\hline & B & Std. Error & & & & Tolerance & VIF \\
\hline $1 \quad$ (Constant) & 398764.236 & 173452.874 & & 2.299 & .033 & & \\
\hline BI_Rate & -5278.078 & 3386.992 & -.077 & -1.558 & .136 & .877 & 1.141 \\
\hline Kurs & -49.305 & 21.342 & -.128 & -2.310 & .032 & .705 & 1.418 \\
\hline Ekspor & 10.385 & .579 & 1.012 & 17.936 & .000 & .678 & 1.476 \\
\hline
\end{tabular}

a. Dependent Variable: Loan

dapat diketahui setiap VIF dari masing-masing variabel bebas $\mathrm{X}$ yaitu : ekspor, tingkat suku bunga, dan kurs, dimana untuk ekspor besarnya $V I F=1.476$, tingkat suku bunga besarnya $V I F=1.141$, kurs besarnya $V I F=1.418$ yang semuanya berada dibawah 2 . Sehingga dapat disimpulkan bahwa untuk ketiga variabel bebas tersebut tidak terjadi multikolinearitas.

Uji Heteroskedastisitas

\section{Scatterplot}

\section{Dependent Variable: Loan}

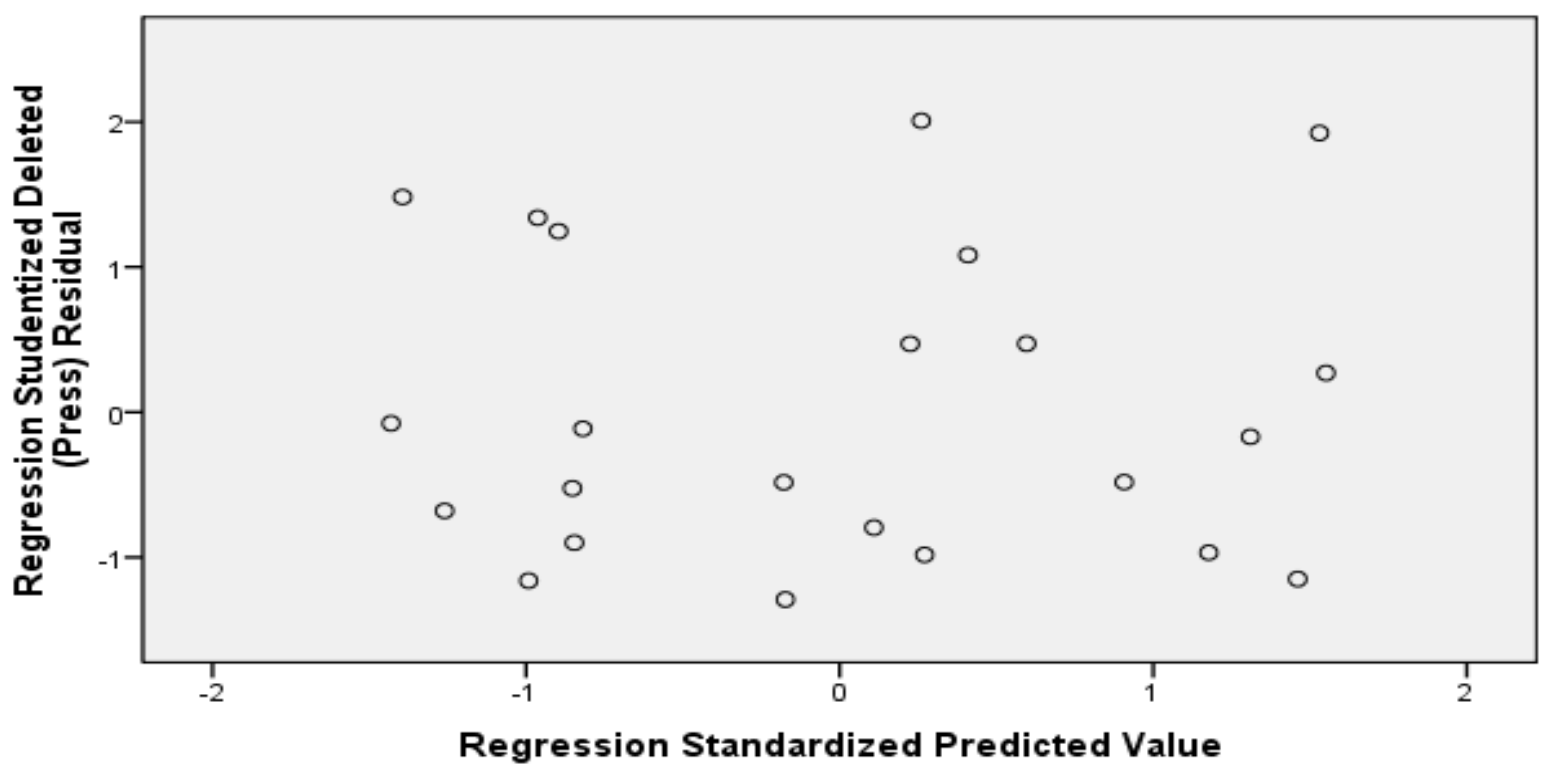

Gambar 3. Scatterplot Residual Untuk Melihat Heteroskedastisitas Kredit 
Uji Autokorelasi

dapat digunakan uji Durbin Watson.

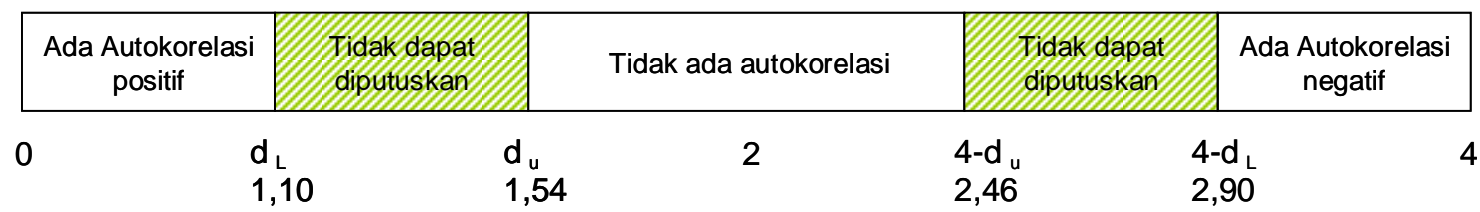

Tabel 8. Model Summary ${ }^{\mathrm{b}}$

\begin{tabular}{|l|l|l|l|l|l|}
\hline Model & $\mathrm{R}$ & R Square & $\begin{array}{l}\text { Adjusted } \\
\text { Square }\end{array}$ & $\begin{array}{l}\text { Std. Error of } \\
\text { the Estimate }\end{array}$ & Durbin-Watson \\
\hline 1 & $.979^{\mathrm{a}}$ & .959 & .953 & 40267.67678 & 1.621 \\
\hline
\end{tabular}

a. Predictors: (Constant), Ekspor, BI_Rate, Kurs

Dari hasil analisis yang dilakukan terhadap jumlah kredit dan ketiga macam jenis kredit lainnya, di dapat persamaan regresi dari masing-masing kredit, kredit modal kerja, kredit investasi, kredit konsumsi yaitu :

- $\quad$ Kredit $=398764.236+10.385$ Ekspor -5278.078 BI Rate -49.305 Kurs

- Kredit Modal Kerja = 265004.170 + 5.245 Ekspor - 1672.188 BI Rate - 31.903 Kurs

- Kredit Investasi = 82112.466 + 1.576 Ekspor - 1841.231 BI Rate - 5.451 Kurs

- Kredit Konsumsi $=51650.748+3.564$ Ekspor -1764.692 BI Rate -11.950 Kurs

Dimana di ketahui bahwa walaupun variabel - variabel makro seperti ekspor, tingkat suku bunga, dan nilai tukar rupiah terhadap USD mempengaruhi jumlah kredit dan ketiga jenis kredit lainnya, tetapi besarnya pengaruh variabel - variabel makro tersebut berbeda untuk masing - masing kredit modal kerja, kredit investasi, dan kredit konsumsi.

Tabel 9. Dampak Hubungan Variabel

\begin{tabular}{|l|l|l|l|}
\hline \multicolumn{1}{|c|}{ Skenario } & Modal Kerja & Investasi & Konsumsi \\
\hline Suku bunga naik & $*$ & $* * *$ & $* *$ \\
\hline Ekspor naik & $* * *$ & $*$ & $* *$ \\
\hline Kurs naik & $* * *$ & $*$ & $* *$ \\
\hline
\end{tabular}

Catatan :

*** : mempunyai dampak paling tinggi

** : mempunyai dampak ditengah-tengah

* : mempunyai dampak paling kecil

Analisis dari tabel diatas :

1. Pergerakan Suku Bunga

Kredit investasi mempunyai dampak yang signifikan dibandingkan kredit yang lain pada saat suku bunga bergerak, ini disebabkan karena kredit investasi digunakan pembelian atau pembangunan suatu infrastruktur yang memiliki masa amortisasi yang panjang sehingga kredit investasi mempunyai jangka waktu yang relatif lebih panjang dibandingkan kredit lain, 
sehingga besar - kecilnya tingkat suku bunga lebih berdampak pada kredit investasi dibandingkan kredit lainnya.

Adapun kredit konsumsi berdampak juga terhadap volatilitas suku bunga karena di dalam kredit konsumsi sendiri terdapat kredit untuk perumahan yang mempunyai jangka waktu yang lama, sehingga membuat sebagian dari kredit konsumsi juga sensitif terhadap volatilitas suku bunga.

\section{Pergerakan Ekspor}

Kredit modal kerja berisikan kredit jangka pendek yang digunakan untuk kepentingan modal untuk kerja atau berproduksi. Karena jangka waktunya yang pendek maka kredit modal kerja tidak terlalu sensitif terhadap volatilitas suku bunga. Kredit modal kerja akan bergerak signifikan apabila ada produksi yang harus dijalankan, sehingga memerlukan modal.

Faktor yang menyebabkan produksi dalam penelitian ini datang dari target ekspor yang tinggi, serta permintaan untuk konsumsi dalam negeri. Kedua faktor tersebut memerlukan hasil dari produksi baik untuk di konsumsi domestik maupun untuk di ekspor keluar negeri.

\section{Pergerakan Kurs}

Kredit modal kerja yang diikuti konsumsi mengalami dampak yang signifikan saat terjadi volatilitas kurs, ini mengindikasikan bahwa bahan baku produksi masih banyak bergantung pada komponen impor, sehingga produksi yang semakin bergantung kepada komponen impor akan mengalami dampak dari pergerakan kurs. Kedua hal ini dapat berhubungan karena bila saja kurs bergerak naik dan suatu produksi sangat bergantung pada bahan baku impor maka bisa saja produksi berhenti dilakukan yang menyebabkan juga tidak adanya peminjaman modal kerja.

Barang konsumsi terdiri dari barang impor, barang lokal, serta barang yang bahan bakunya impor ataupun lokal sehingga memiliki juga pengaruh disaat nilai tukar rupiah bergerak, namun dengan adanya pilihan substitusi barang lokal dan impor membuat kredit konsumsi berada ditengah - tengah untuk signifikasi terhadap kurs.

\section{KESIMPULAN DAN SARAN}

\section{Kesimpulan}

Dari hasil penelitian yang telah dilakukan maka dapat disimpulkan sebagai berikut :

- Pengaruh indikator makro seperti ekspor, tingkat suku bunga, dan nilai tukar rupiah terhadap USD memberikan dampak yang berbeda - beda terhadap kredit dan juga tiga macam jenis kredit yang terdiri dari kredit modal kerja, kredit investasi, dan kredit konsumsi. Dari hasil penelitian dapat disimpulkan bahwa jumlah ekspor berjalan searah dengan jumlah kredit dan ketiga jenis macamnya dimana jika ekspor mengalami kenaikan maka seluruh macam kredit juga mengalami kenaikan. Tingkat suku bunga bergerak berlawanan terhadap jumlah kredit maupun ketiga macam jenis kredit lainnya, dimana jika tingkat suku bunga bergerak naik maka akan mengurangi jumlah kredit termasuk didalamnya kredit modal kerja, kredit investasi, dan kredit konsumsi. Sama dengan pengaruh tingkat suku bunga, pengaruh nilai tukar terhadap jumlah kredit dan ketiga jenis kredit lainnya berpengaruh secara berlawanan, dimana jika kurs naik maka akan 
mengurangi jumlah kredit baik itu kredit modal kerja, kredit investasi, maupun kredit konsumsi.

- Walaupun masing-masing indikator makro mempengaruhi jumlah kredit termasuk ketiga jenis kredit lainnya dengan arah yang sama, namun besarnya pengaruh masing - masing indikator makro tersebut berbeda - beda diantara kredit modal kerja, kredit investasi dan kredit konsumsi. Tingkat suku bunga mempengaruhi paling besar jumlah kredit investasi, diikuti oleh kredit konsumsi, dan terakhir kredit modal kerja.

- Jumlah ekspor mempengaruhi paling besar jumlah kredit modal kerja, diikuti oleh kredit konsumsi dan terakhir kredit investasi. Nilai tukar rupiah terhadap USD berpengaruh paling besar terhadap kredit modal kerja, diikuti oleh kredit konsumsi dan terakhir kredit investasi.

\section{Saran}

- Untuk penelitian lebih lanjut, dapat dilakukan dengan penambahan variabel variabel makro lainnya seperti Gross Domestic Product, jumlah uang beredar, rencana penanaman modal dalam negeri dan variabel lainnya untuk melihat lebih jauh kedinamisan pergerakan kredit dan ketiga macam kredit lainnya terhadap jenis variabel makro lainnya.

- Karena pemberian kredit oleh bank bergantung kepada jumlah penghimpunan dana pihak ketiga yang dapat dihimpun perbankan maka kiranya perlu juga diteliti pengaruh indikator - indikator makro tersebut terhadap pergerakan penghimpunan dana pihak ketiga yang terdiri dari giro, tabungan, dan simpanan berjangka.

- Bank di Indonesia berjumlah sangat banyak, dimana masing-masing mempunyai keunikan dan kekuatan masing-masing atas suatu segmen yang mereka pilih. Segmen yang berbeda ini menyebabkan beragamnya portfolio kredit yang perbankan miliki yang terbagi menjadi tiga garis besar, yaitu : Kredit konsumsi, modal kerja dan investasi . Untuk investor perbankan, dengan hasil penelitian ini diharapkan para investor dapat melihat dengan lebih baik arah kedepan dari bank yang akan mereka miliki dengan memperhitungkan trend makro ekonomi. Sehingga ekspektasi atas performa bank yang dipilih dapat diperkirakan dari awal. Saran lainnya adalah dalam memilih investasi di bank agar diperhatikan rasio-rasio kunci lainnya seperti kecukupan modal (CAR), ROE, PPAP/PPAPWD untuk mengetahui kemampuan bank membentuk pencadangan atas kredit bermasalah, makin besar PPAP/PPAPWD nya berarti bank tersebut memiliki pencadangan yang lebih besar dari yang seharusnya dibentuk oleh regulator perbankan. Bersama dengan hasil penelitian maka pihak investor dapat mengakses dan menganalisa apakah strategi dan target yang ditetapkan oleh bank terhadap masing-masing golongan kredit tersebut sesuai dengan arah dari proyeksi dan target indikator makro yang ada. 


\section{DAFTAR PUSTAKA}

Aczel, Amir D. (2005). Complete Business Statistics. 6th ed. Irwin McGraw-Hill Book Co.

Gardner Mona J, Mills Dixie L \& Cooperman Elizabeth S. (2005). Managing Financial Institutions. $5^{\text {th }}$ ed. USA: South - Western/Part of Thomson Corporation, Inc.

Executive summary hasil penelitian kerjasama antara Kantor Bank Indonesia Semarang dengan Pusat Pengkajian dan Pengembangan Manajemen Fakultas Ekonomi UNIKA Soegijapranata Semarang. http://www.bi.go.id/NR/rdonlyres/C73557EE-8AC6-4CB6BB28-E517D554397C/5646/Boks2.pdf

Hubbard R. G. \& A. P. O’Brien. (2006). Economics. Singapore: Pearson Prentice.

http://www.bi.go.id/NR/rdonlyres/8EFDC99E-8888-4D63-ADACB37F5BEC2039/9618/Tahun2007.pdf

http://www.bi.go.id/ http://www.bi.go.id/web/id/Data+Statistik/statcat.htm?head=43\&lang=\&stat=io http://www.bi.go.id/web/id/Data+Statistik/statcat.htm?head=122\&lang=\&stat=io http://www.bi.go.id/web/id/Data+Statistik/statcat.htm?head=132\&lang=\&stat=io http://www.bi.go.id/web/id/Data+Statistik/statcat.htm?head=18\&lang=\&stat=io http://www.bi.go.id/web/id/Data+Statistik/statcat.htm?head=22\&lang=\&stat=io http://www.bi.go.id/web/id/Data+Statistik/statcat.htm?head=20\&lang=\&stat=io http://www.bi.go.id/web/id/Data+Statistik/statcat.htm?head=24\&lang=\&stat=io http://id.wikipedia.org/wiki/Bank http://id.wikipedia.org/wiki/Ekspor http://id.wikipedia.org/wiki/Uang http://www.bankniaga.co.id [2008, Maret 20] http://www.bca.co.id [2008, Maret 20] http://www.bi.go.id/web/id/Data+Statistik/statcat.htm?head=111\&lang=\&stat=io http://id.wikipedia.org/wiki/Inflasi http://id.wikipedia.org/wiki/Jenis-jenis uang http://id.wikipedia.org/wiki/Uang

Indonesia, Ikatan Akuntan. (2001). Pedoman Akuntansi Perbankan Indonesia Revisi 2001. $1^{\text {st }}$ ed. Jakarta: Direktorat Penelitian dan Pengaturan Perbankan, Bank Indonesia.

Irmayanto, Juli., dkk. (2002). Bank dan Lembaga Keuangan. Jakarta: Penerbit Universitas Trisakti.

Judisseno, Rimsky K. (2002). Sistem Moneter Dan Perbankan Di Indonesia. Jakarta: PT. Gramedia Pustaka Utama.

Kasmir. (2001). Bank dan Lembaga Keuangan Lainnya. Edisi 6. Jakarta: Divisi Buku Perguruan Tinggi PT Raja Grafindo Persada. 
Keown Arthur J., Martin John D., Petty J. William \& Scott David F. (2005). Financial Management : Principles and Applications. $10^{\text {th }}$ ed. New Jersey: Pearson Prentice Hall.

Levine, Stephan, Krehbiel, \& Brenson. (2005). Statistics for Managers. $4^{\text {th }}$ ed. Prentice Hall.

Madura, Jeff. (2006). International Corporate Finance. $8^{\text {th }}$ ed. USA: South-Western.

Mc Taggart Douglas, Findlay Christopher \& Parkin Michael (2003). Economics. $4^{\text {th }}$ ed. Australia: Pearson Education.

Muljono, Teguh Pudjo. (1999). Analisa Laporan Keuangan Untuk Perbankan, Edisi 6. Jakarta: Djambatan.

Prawira, W. Putu Gedhe. (2001). Kewirausahaan Di Bidang Ekspor. Jakarta: STIE IBII.

Punan, Ignatius Berry. (1996). Sebelas Strategi Dasar dan Selusin Kesalahan Umum Pemasaran Ekspor. Jakarta: Mega Media Abadi.

Punann, Ignatius Berry. (1996). Teknik dan Strategi Bisnis Ekspor di Indonesia. Yogyakarta Yayasan Pustaka Nusatama.

Singgih Santoso. (2005). Menguasai Statistik di Era Informasi dengan SPSS versi 12. Jakarta: PT. Elex Media Komputindo.

Siagian Dergibson. (2000). Metode Statistika Untuk Bisnis dan Ekonomi. Jakarta: PT. Gramedia Pustaka Utama.

Singgih Santoso. (2000). SPSS Statistik Parametrik. Jakarta: PT. Elex Media Komputindo.

Soleh Achmad Zanbar. (2005). Ilmu Statistika: Pendekatan Teoritis dan Aplikatif. $1^{\text {st }}$ ed. Bandung: Rekayasa Sains.

Subagyo, Fatmawati Sri, Badrudin Rudy, Purnamawati Astuti, \& Algifari. (2002). Bank dan lembaga keuangan lainnya. Edisi 2. Yogyakarta: Yayasan Keluarga Pahlawan Negara.

Sukirno Sadono. (1997). Pengantar Makroekonomi. Edisi 2. Jakarta: PT Raja Grafindo Persada.

Trihendradi, C. (2007). Kupas Tuntas Analisis Regresi. Yogyakarta: CV ANDI OFFSET.

Undang-Undang Republik Indonesia Nomor 7 Tahun 1992, Tentang Perbankan

Undang-Undang Republik Indonesia Nomor 10 Tahun 1998, Tentang Perubahan Atas Undang-Undang Republik Indonesia Nomor 7 Tahun 1992 Tentang Perbankan 
Undang-Undang Republik Indonesia Nomor 23 Tahun 1999, Tentang Bank Indonesia

Undang-Undang Republik Indonesia Nomor 3 Tahun 2004 Tentang Perubahan Atas UndangUndang Republik Indonesia Nomor 23 Tahun 1999 Tentang Bank Indonesia

Winarno, Wing Wahyu. (2007). Analisis Ekonometrika dan Statistika dengan EVIEWS. Yogyakarta: UPP STIM YKPN. 